political agency, and for what purpose, besides hers and her offspring's sheer survival, did Hürrem exercise is quite unclear. The one work, which would provide a corrective to Peirce's lofty claims of Haseki Hürrem's political role, Baki Tezcan's The Second Ottoman Empire: Political and Social Transformation in the Early Modern World (2010), is strangely missing from the bibliography. The unfortunate impression is that Peirce has an agenda to push and to that end all means are good.

Are we then dealing with a rich, professionally rigorous reconstruction of a great personage's life and struggles or a rosy, popular interpretation on a par with the Turkish TV soap opera series The Magnificent Century? Fans of both varieties of history will doubtlessly take something away from Empress of the East; perhaps (to echo Peirce), this is what ultimately matters.

KIRIL PETKOV

University of Wisconsin-River Falls

\title{
Women as Essential Citizens in the Czech National Movement: The Making of the Modern Czech Community. By Dáša Frančíková. Lanham: Lexington Books, 2017. 141 pages. Notes. Bibliography. Index. Hard Bound. doi: 10.1017/slr.2018.219
}

Dáša Frančíková's book examines the various roles that early nineteenth-century middle-class Czech women were assigned, and that they fashioned for themselves, during the early stages of the Czech national movement for linguistic, literary, cultural (and later also political) independence. The author's focus on the 1820s through the 1850s is particularly welcome since this historical period remains still fairly unexplored in the English-language scholarship on nineteenth-century Czech women's lives and work.

Frančíková sets out to explore how the "earlier nineteenth-century members of the Czech community strove to create and naturalize [the definition of] 'woman' who they thought could best serve the purpose of the Czech nation and community" (xv). In chapter one, she outlines the role of women such as Antonie Bohuslava Rajská or Honorata Zapová in the production of this construct. Likewise, she traces some of the ways in which Czech women at the time negotiated, stretched, and re-shaped the construct as they lived their lives and as they worked to produce the sensibility and reality of the Czech national community.

Particularly notable in this context is Frančíkovás reading, in Chapter 3, of the story "Kateřina Maršalová, amazonka česká” (Kateřina Maršalová, the Czech Amazon). This story, published in 1845 in the weekly Květy, was brought to light through Frančíková's archival research. It celebrates the life of Maršalová, an eighteen-century Czech woman (whether fictional or historical) who-disguised as her brother-took up the life of a dragoon in the Austrian army. Maršalová was successful in her disguise and in her career for years, the story asserts, and after being finally discovered, she was invited to the imperial court and (rather than rebuked) she was praised and rewarded by the empress Maria Theresa. In Frančíková's reading, the story challenges the accepted assumptions about the period image of ideal Czech womanhood, since Maršalová, who does later in the story marry and bear children but whose husband and children all die prematurely, is here represented sympathetically.

Chapter 2 of the book, which focuses on several romantic friendships between renowned Czech women, including the friendship between Božena Němcová and Sofie Rottová, is equally fascinating. Researching the book, Frančíková conducted 
extensive archival work and unearthed significant to-date unknown or neglected texts, including novels, short stories, and advice literature, as well as unpublished correspondence and diaries. In Chapter 2, she uses these original texts, and especially letters, to shed new light on the central role that women's friendships with other women played in nourishing their lives and in sustaining their community-building activities.

While the focus of Frančíková's book remains on the Czech setting, the author also makes consistent efforts to place the achievements and challenges faced by earlier nineteenth-century Czech women within the broader central European and Euro-American context. For instance, Chapters 4 and 5, which explore the topic of the Czech community members' health and fitness, especially focusing on the popularity of hydrotherapy, compare some of the Czech nation-building discursive strategies with those deployed in other national settings at the time. These chapters work to place what was happening in the Czech setting within the broader context of the preDarwinian biopower, as it was emerging as a new technology of power throughout Europe at the time.

Neither in these two last chapters nor in the rest of the book do issues of whiteness come up. This is unfortunate, considering that the topic of biopower, explored in the book's final chapters, would seem to lend itself particularly well to the exploration of the extent to which non-whiteness was (or was not) a category used to exclude some of those who lived in the Czech lands from membership in the fledgling national community. This question remains unaddressed in the book. But Frančíková does make some interesting observations concerning the linguistic and national pedigree of several of the female members of the Czech nation-building project. From today's perspective, it is intriguing to ponder that Rajská, the perhaps most renowned of the early nineteenth-century Czech women nation builders, was born to a German family that had moved to Prague. And another prominent community member, Honorata Zapová, was Polish, although married to a Czech. The power of language to construct Czechness is well explored in the book, although it would perhaps have been fitting to also examine the extent to which whiteness was (or was not) emerging as a relevant category in the Czech community at the time.

IVETA JusovÁ Carleton College

The Czech and Slovak Republics: Twenty Years of Independence, 1993-2013. Ed. M. Mark Stolarik. Budapest: Central European University Press, 2016. xiv, 364 pp. Notes. Bibliography. Index. Tables. $\$ 60.00$, hard bound. doi: 10.1017/slr.2018.220

Growing out of a conference held at the University of Ottawa in 2013, M. Mark Stolarik's edited volume brings together the work of scholars from North America and the Czech and Slovak Republics. The conference and subsequent publication had two main goals: to reevaluate the "Velvet Divorce," the peaceful agreement that led to Czechoslovakia's split, and to compare the post-divorce trajectories of the two independent states. Stolarik's comprehensive introduction names the "debate over issues of individual agency and deeper political structures" as the most striking theme of the volume. The authors analyze the split's main causes and question its inevitability by exploring the emergence of nationalism and national identity, cultural and economic factors, political elites, and public opinion. The chapters represent a wide array of disciplinary approaches, including history, economics, political science, 